\title{
Experimental challenge of Atlantic salmon Salmo salar using clones of Paramoeba perurans, $P$. pemaquidensis and Tetramitus sp.
}

\author{
Are Nylund ${ }^{1, *}$, Martin Røed $^{1}$, Steffen Blindheim ${ }^{2}$, Christiane Trösse $^{1}$, \\ Linda Andersen ${ }^{2}$ \\ ${ }^{1}$ Department of Biology University of Bergen, 5020 Bergen, Norway \\ ${ }^{2}$ The Industrial and Aquatic Laboratory (ILAB), Thormøhlensgt 55, 5006 Bergen, Norway
}

\begin{abstract}
Salmon gill disease in Norway is in most cases associated with a range of different pathogens, stress and environmental factors. Paramoeba perurans and other amoebae have been isolated during such disease outbreaks. Other amoebae isolated from salmon with gill disease in Norway include P. pemaquidensis, Tetramitus sp. and Vannella sp. Here we tested the pathogenicity of the first 2 species in challenge experiments. We found that even when clonal cultures of $P$. pemaquidensis established an infection on the gills of salmon, it failed to cause gill disease, while Tetramitus sp. appeared to be unable to establish a lasting infection on the gills of healthy salmon. The result of the challenge with $P$. pemaquidensis confirms the results of similar studies performed in the USA and in Australia. Tetramitus sp. is probably a common amoeba in the marine environment, and its presence on the gills of farmed salmon may just be accidental. Based on this study, we conclude that $P$. perurans is the only known amoeba in marine salmon farming associated with amoebic gill disease in Norway.
\end{abstract}

KEY WORDS: Salmo salar - Amoebic gill disease - Paramoeba pemaquidensis $\cdot P$. perurans $\cdot$ Tetramitus sp. · Vannella sp. · Virulence

\section{INTRODUCTION}

Gill disease (GD) of Atlantic salmon Salmo salar has been an increasing problem in Norwegian aquaculture since 2000 (Nylund et al. 2007, 2008, 2011, Steinum et al. 2008). Damage to the gills may lead to respiratory and circulatory problems, resulting in reduced fish welfare and growth, and in some cases increased mortality (Powell et al. 2000). Farmers in western Norway often experience increased mortalities in the farms during stressful periods, including handling of the fish and in connection with mechanical treatments of salmon with lice infections (Overton et al. 2019, Walde et al. 2021, A. Nylund pers. obs.).

*Corresponding author: are.nylund@uib.no
The causes for GD are complex, and a range of different pathogens (viruses, bacteria and microparasites) are associated with these gill health problems. The most common pathogens associated with GD in Norway are Paranucleospora theridion (syn. Desmozoon lepeophtheirii), Paramoeba perurans (syn. Neoparamoeba perurans), Ichthyobodo salmonis, Tenacibaculum maritimum, Candidatus Branchiomonas cysticola, other epitheliocystis-causing agents $(C$. Piscichlamydia salmonis, $C$. Syngnamydia salmonis, $C$. Clavichlamydia salmonicola) and salmonid gill pox virus (SGPV) (Nylund et al. 2006, 2008, 2010, 2011, 2015, Karlsen et al. 2008, Isaksen et al. 2011, Mitchell et al. 2013, Småge et al. 2016, Downes et al. 2018). An addi-

() The authors 2021. Open Access under Creative Commons by Attribution Licence. Use, distribution and reproduction are unrestricted. Authors and original publication must be credited. 
tional microparasite (Parvicapsula pseudobranchicola), associated with pseudobranchs and gills of salmon, is causing problems in northern Norway (Karlsbakk et al. 2002, Nylund et al. 2018a).

It was initially believed that Paramoeba pemaquidensis caused amoebic gill disease (AGD) in salmon, and it has also been suggested that other amoebae such as Platyamoeba spp. could play a role in development of AGD (Kent et al. 1988, DouglasHelders et al. 2000, Munday et al. 2001, Bermingham \& Mulcahy 2007). AGD was induced under laboratory conditions by exposing naïve salmon to AGDaffected salmon or by exposing naïve salmon to purified amoeba trophozoites from AGD-affected salmon (Zilberg et al. 2001, Morrison et al. 2004). In a challenge experiment, isolates of $P$. pemaquidensis obtained from salmon with AGD failed to cause AGD in naïve salmon (Kent et al. 1988, Morrison et al. 2005). After the discovery and characterization of Paramoeba perurans from gills of farmed salmon in Australia and Norway, it was thought that this is the primary causative agent of AGD (Nylund et al. 2007, 2008, Young et al. 2007, 2008, Steinum et al. 2008). Later challenge experiments showed that inoculums containing clonal cultures of $P$. perurans can reproduce AGD in farmed salmon (Crosbie et al. 2012, Røed 2016, Kindt 2017, Dahle et al. 2020). P. perurans has been detected in marine fish aquaculture worldwide (Steinum et al. 2008, Young et al. 2008, Bustos et al. 2011, Karlsbakk et al. 2013, Mouton et al. 2014, Oldham et al. 2016, Haugland et al. 2017, Kim et al. 2017).

AGD is characterized by increased mucus production and hyperplasia causing white patches on the gills and resulting in reduced respiratory surface area (Adams \& Nowak 2004, Powell et al. 2015). The hyperplasia may result in interlamellar fusion and sometimes the formation of vesicles containing $P$. perurans. The resulting gill damage/changes have, during the last decade, been classified using a gill score system (Taylor et al. 2009).

In the years following the first reports of AGD in 2006 there were no reports of GD caused by $P$. perurans in western Norway, but since 2012, AGD has been a constant challenge for salmon production in this part of the country. As part of the increased focus on GD in Norway, the Fish Diseases Research Group (FDRG) at the University of Bergen started a project on isolation of amoeba from salmon affected by GD. The major focus was on isolation and cloning of $P$. perurans from salmon with AGD, but culturing of amoebae was also attempted from salmon with GD that were negative for $P$. perurans. The result of this work led to the isolation of Paramoeba pemaquidensis, Vannella sp. and Tetramitus sp. from saithe Pollachius virens, ballan wrasse Labrus bergylta and Atlantic salmon. Several other amoebae had previously been identified on the gills of farmed salmon suffering from AGD in Ireland and Tasmania (Bermingham \& Mulcahy 2007, English et al. 2019), but this is the first time Tetramitus sp. has been isolated from the gills of salmon.

The present study gives a short description of the GD associated with P. pemaquidensis and Tetramitus sp. isolated from farmed salmon and the result of challenge experiments using clones of these 2 amoebae species. Different clones of P. perurans were also included in the challenge experiments as positive controls.

\section{MATERIALS AND METHODS}

\subsection{Isolation and cloning of amoebae}

During a project focussing on AGD, attempts were made to isolate Paramoeba perurans from the gills of salmon suffering from this disease and from other GDs. Primary isolates of amoebae were obtained by adding gill tissue onto malt-yeast agar (MYA; $0.01 \%$ Bacto $^{\mathrm{TM}}$ Malt Extract, $0.01 \%$ Bacto $^{\mathrm{TM}}$ Yeast Extract, 2.0 Bacto $^{\mathrm{TM}}$ Agar in $34 \%$ sterile seawater) with a layer of sterile seawater covering the tissue (Crosbie et al. 2012). The cultures were kept at $15^{\circ} \mathrm{C}$, and when amoebae could be observed, the isolates were grown for 3 passages before cloning (Nylund et al. 2018b). Clonal cultures of the amoebae were established as described by Nylund et al. (2018b).

The identity of the amoebae was established by sequencing the partial small subunit (SSU) rRNA gene from cloned amoebae. Three different species of amoeba were isolated in addition to $P$. perurans. These were isolates both from salmon diagnosed with AGD and from salmon with less specific GDs in addition to cleaner fish and saithe present in salmon cages. Three isolates of $P$. pemaquidensis (clones H10/14Pq, H09/14Pq and H17/15Pq) were obtained from saithe, ballan wrasse and salmon, respectively. Ballan wrasse were used as cleaner fish for removal of salmon lice and therefore co-habitated with salmon suffering from AGD. P. pemaquidensis clone H09/14Pq was obtained from a saithe trapped inside a cage with salmon showing signs of GD. Tetramitus sp. was obtained from farmed salmon with GD in western Norway (Sogn og Fjordane and Hordaland 
counties) in 2013 (clone SF05/13T) and 2015 (clone H16/15T). A Vannella sp. isolate was obtained from salmon lice Lepeophtheirus salmonis present on farmed salmon with GD in Hordaland. Vannella spp. have previously also been found on the gills of salmon in Australia and Ireland (Bermingham \& Mulcahy 2007, English et al. 2019).

Two of these species, $P$. pemaquidensis (clones H09/14Pq and H17/15Pq) and Tetramitus sp. (clone H16/15T), in addition to 3 clones of $P$. perurans, were used to challenge salmon to see if they could cause AGD or GD (Table 1). The 3 P. perurans isolates were obtained from farmed Atlantic salmon in 2 counties (Sogn og Fjordane clone SF11/15Pp, Møre og Romsdal clone MR06/14Pp) and from ballan wrasse in Hordaland county (clone H04/14Pp). The 2 control groups received only culture media (malt-yeast broth, MYB).

Table 1. Cloned amoebae used in the challenge experiment, species, host species (isolation source) and date of isolation. For all challenges, the dosage used was 1000 amoebae $\mathrm{l}^{-1}$, the number of salmon bath-challenged (shedders) was 30 , and the number of co-habitants added $7 \mathrm{~d}$ after challenge was also 30

\begin{tabular}{|lccc|}
\hline Clone & Species & $\begin{array}{c}\text { Host } \\
\text { species }\end{array}$ & $\begin{array}{c}\text { Date of } \\
\text { isolation }\end{array}$ \\
\hline H04/14Pp & Paramoeba perurans & Labrus bergylta & 27.08 .2014 \\
SF11/15Pp & P. perurans & Salmo salar & 05.02 .2015 \\
H09/14Pq & P. pemaquidensis & Labrus bergylta & 02.10 .2014 \\
MR06/14Pp & P. perurans & Salmo salar & 18.11 .2014 \\
H16/15T & Tetramitus sp. & Salmo salar & 10.09 .2015 \\
H17/15Pq & P. pemaquidensis & Salmo salar & 27.08 .2015 \\
\hline
\end{tabular}

\subsection{Challenge experiment}

The challenge experiment was carried out at the Industrial and Aquatic Laboratory (ILAB) in Bergen in autumn 2015. The Atlantic salmon used (average weight $=127.7 \mathrm{~g}$ and length $=23.7 \mathrm{~cm}$ ) came from a freshwater site in western Norway and were acclimatized to and kept at $12.0 \pm 0.8^{\circ} \mathrm{C}$ in full seawater (salinity $=35 \pm 0.1 \%$ ) in 8 tanks $(150 \mathrm{l})$ with 30 specimens in each tank. An additional 240 salmon were kept in separate tanks for later use as co-habitants. Before the start of the challenge experiment, gill tissues from 30 of the salmon in the original stock were tested with respect to microparasites (viruses, bacteria and protozoans) known to be present in salmon held in freshwater at Norwegian smolt production sites. The following microparasites were included in the real-time RT-PCR test of the gill tissues: infectious salmon anaemia virus (ISAV) (Plarre et al. 2005), salmonid alphavirus (SAV) (Hodneland \& Endresen 2006), Infectious pancreatic necrosis virus (IPNV) (Nylund et al. 2011), Piscine orthoreovirus (PRV1) (Nylund et al. 2018a), SGPV (Table 2), Candidatus Piscichlamydia salmonis (Duesund et al. 2010), C. Branchiomonas cysticola (Nylund et al. 2018a) and Ichthyobodo spp. (Isaksen et al. 2012). All 30 salmon tested were negative for the presence of these pathogens.

Table 2. Primers and probes used for real-time RT-PCR detection of Paramoeba pemaquidensis (Neo-uni), Tetramitus sp. (Tssu), Vannella sp. (Van) and salmonid gill pox virus (SGPV). The names of the primers and probes, their sequences, GenBank accession numbers, efficiency (=10 [-1/slope]) and product sizes (length) are shown

\begin{tabular}{|c|c|c|c|c|}
\hline Primer/probe & Sequence & Accession no. & Efficiency & Length (nt) \\
\hline Tssu-F & AAA CGC CCG TAG TAA ACC AAA G & & & \\
\hline Tssu-probe & ACT GAT CTG ATC GGT TCT & МT021911 & 1.98 & 70 \\
\hline Tssu-R & CGT GGC CGA CTA TGA TGG A & & & \\
\hline NeoUni-F & TTG TCA GAG GTG AAA TTC TTG GAT T & & & \\
\hline NeoUni-probe & ATG AAA GAC GAA CTT CTG & MT665807 & 2.01 & 71 \\
\hline NeoUni-R & TGA AAA CAT CTT TGG CAA ATG C & & & \\
\hline Van-F & TCG GAA TGG TTG GCA CTT ATT & & & \\
\hline Van-probe & GAA GAA GTA TTG GTT TGT TA & МТ014020 & 1.98 & 86 \\
\hline Van-R & CAT GCG ATC TGT TCA GTT ATT ATG AA & & & \\
\hline SGPV-MCP-F & CAG AGG TTT TTC ATA CGC CAG AA & & & \\
\hline SGPV-MCP-probe & TTA TAC ACC ATC ACA TTT GTG & MH061372 & 1.97 & 84 \\
\hline SGPV-MCP-R & GAG GTC ACG GTG ATG ACA GAA C & & & \\
\hline
\end{tabular}


The challenge experiments included 2 control groups (Con-I and Con-II; each group had pure/sterile culture medium instead of media containing amoebae or bacteria), 3 clones of Paramoeba perurans, 2 clones of $P$. pemaquidensis and 1 clone of Tetramitus sp. (Table 1). The salmon in each tank were challenged with 1000 amoeba ${ }^{-1}$ in a volume of 1001 aerated seawater. The 2 control groups were given equal amounts of culture media, equivalent to the amount of media with amoebae added to the experimental tanks. After $60 \mathrm{~min}$, the water flow was reinstated, and the volume was increased to $150 \mathrm{l}$ in all 8 tanks. The salmon were kept in a flow-through system during the rest of the experiment. Co-habitants $(\mathrm{N}=30)$ were added $7 \mathrm{~d}$ post challenge $(\mathrm{dpc})$ to each of the 8 tanks (Table 1). The shedders (i.e. bathchallenged salmon) in each tank were sampled at 6, 13 and $20 \mathrm{dpc}$, while the co-habitants were collected on Days 11, 18 and 25 after being added to the tanks (Fig. 1).

Weight, length and gill score were registered for all fish sampled. The gill score was calculated for both sides on all 8 gill arches (Taylor et al. 2009). A $100 \%$ score was given when all sides had a gill score $=5$ (an average gill score of 3 on all 16 sides $=60 \%$ ). The gill score obtained in the challenge experiment is given as a percentage of maximum score possible.

Gill tissues for real-time RT-PCR detection of the amoebae and sequencing were collected from the second gill arch of the left side, while the third gill arch on the left side was sampled for histology.
Amoebae used in the challenge experiment were re-isolated from co-habitants collected $25 \mathrm{dpc}$, as described by Morrison et al. (2004). Two gill arches with visible 'patches', indicating AGD, were sampled from the salmon. One of the gill arches was added to a cell culture flask $\left(25 \mathrm{~cm}^{2}\right)$ containing MYB (gill arch was removed after $15 \mathrm{~h}$ ). The second gill arch was streaked onto a petri dish (MYA) to which sterile seawater was added. The samples were checked during the following $7 \mathrm{~d}$ for growth of amoebae. If positive, they were tested by real-time RT-PCR and sequenced by Sanger sequencing of the SSU rRNA gene from the amoebae.

The experiment was approved by the Norwegian Food Safety Authority according to the European Union Directive 2010/63/EU for animal experiments (permit numbers 7904 and 9066). All fish were treated according to the Norwegian Animal Welfare Act (01/01/2010).

\subsection{Histology}

Gill tissues from salmon suffering from AGD or GD at marine production sites and gills from salmon challenged with Paramoeba perurans, P. pemaquidensis and Tetramitus sp. were fixed in a modified Karnovsky fixative (Steigen et al. 2013). The tissues were embedded in EMBED 812, and semi- and ultrathin sections were cut from the resin blocks and used for light and transmission electron microscopic (TEM) studies.

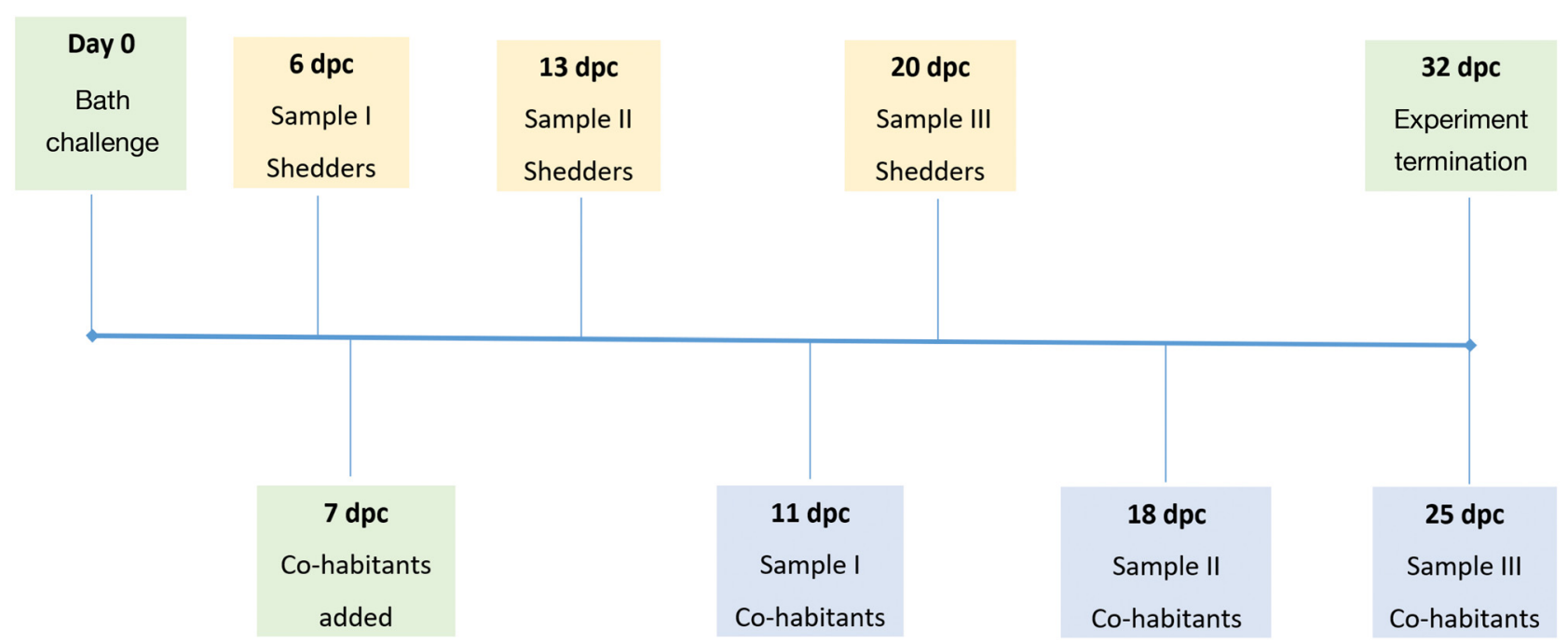

Fig. 1. Timeline for the challenge experiment. Salmon (shedders) were bath-challenged on Day 0, and co-habitants were added $7 \mathrm{~d}$ post challenge (dpc). Shedders were sampled $(\mathrm{N}=10$ at each sampling point) at 6,13 and $20 \mathrm{dpc}$, while the co-habitants were sampled ( $\mathrm{N}=10$ at each sampling point) at 11, 18 and $25 \mathrm{dpc}$ (after being added to the tanks) 


\subsection{RNA/DNA extractions and sequencing}

RNA was extracted as described by Gunnarsson et al. (2017a), and DNA was extracted using the DNeasy DNA Tissue kit (Qiagen) as recommended by the manufacturer. Elution of the DNA was performed twice in $50 \mu$ l of $10 \mathrm{mM}$ Tris- $\mathrm{HCl}$ (pH 8.5), to increase the overall DNA yield. RNA and DNA were stored at $-20^{\circ} \mathrm{C}$ until use.

The DNA extracted from the clonal cultures of the amoebae was used to sequence the SSU rRNA gene for identification of genus and species. In addition to 3 clonal cultures of $P$. perurans, 3 cultures of $P$. pemaquidensis (GenBank accession nos. MT665807, MT665808, MT665809), 2 cultures of Tetramitus sp. (MT021911) and 1 culture of Vannella sp. (MT014020) were identified. The Vannella sp. showed 99.4\% sequence identity (1886 nucleotides of the rRNA SSU gene) to $V$. contorta (DQ229953) isolated from water samples obtained at $10 \mathrm{~m}$ depth from the north edge of the Ross Sea pack ice (Moran et al. 2007).

\subsection{Real-time RT-PCR and normalization of data}

New real-time RT-PCR assays were developed targeting the SSU rRNA of Tetramitus sp. and Vannella sp. (Table 2), while an assay targeting the SSU rRNA from $P$. perurans has already been published (Nylund et al. 2018b). P. pemaquidensis were detected on the gills of challenged salmon using an assay (NeoUni) targeting the SSU rRNA gene of Paramoeba spp. (Table 2). Standard curves for the assays were generated by using a 10-fold dilution series of RNA in triplicates, and the PCR efficiency ( $E=10[-1 /$ slope $]$ ) was calculated (Nylund et al. 2018b). A previously developed assay (EF1A, E = 1.94, Olsvik et al. 2005) targeting the elongation factor 1 alpha, was used as an internal standard when running real-time RT-PCR on gill tissues.

The normalized expression (NE) of the amoebae SSU rRNA gene was calculated using the formula

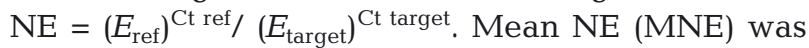
calculated from the NE values.

\subsection{Phylogeny}

Preliminary species identification of the amoebae clones, using 18S rRNA (Tetramitus sp.: 2085 nucleotides [nt], Vannella sp.: 1886 nt, P. pemaquidensis: $1860 \mathrm{nt}$ ), was performed by searching the public
GenBank database for related homologous sequences using BLAST (2.0). The Vector NTI Suite software package was used to generate multiple alignments of the sequences. Selected sequences from existing genera, available on the EMBL nucleotide database, were included in pairwise sequence comparisons. The multiple sequence alignment editor GeneDoc (www.psc.edu/biomed/genedoc) was used for manual adjustment of the sequence alignments (gaps in the alignments were removed). A maximum likelihood tree was generated and bootstrapped (50000 puzzling steps) in TREE_PUZZLE 5.2 (current version; www.tree-puzzle.de). Phylogenetic trees were drawn using FigTree (v1.4.3, A. Rambaut)

\section{RESULTS}

\subsection{Salmon gills from field samples}

Tetramitus sp. was associated with GD in Atlantic salmon in 2 counties in western Norway: Hordaland (isolate: H16/15T) and Sogn og Fjordane (isolate: SF05/13T). Gills from the salmon in Hordaland showed areas of necrotic tissue, loss of tissue and hyperplasia (Fig. 2). Several pathogens were present in the gills of the salmon: Paramoeba perurans (Syn. Neoparamoeba perurans), Tetramitus sp., Ichthyobodo salmonis, Paranucleospora theridion (syn. Desmozoon lepeophtheirii), Candidatus Branchiomonas cysticola and SGPV. A few salmon were also positive for SAV. The salmon with GD in Sogn og Fjordane had pale gills, increased mucus production and gill bleeding (aneurism), and were positive for Tetramitus sp., Paranucleospora theridion, Ichthyobodo salmonis, Cand. Branchiomonas cysticola, Tenacibaculum spp. and SGPV (Fig. 2). Histological changes of the gill tissue and presence of putative amoebae associated with the gills are presented in Fig. 2E-H. A clonal isolate of Tetramitus sp. (SF05/13T) is shown in Fig. 3. All salmon from the 2 farms were also positive for PRV1. Based on phylogenetic analysis of the SSU rRNA gene (accession no. MT021911), the closest relative to the 2 Tetramitus $\mathrm{sp}$. clones is T. vestfoldii isolated from Pendent Lake, Vestfold Hills, eastern Antarctica (Murtagh et al. 2002) (see Fig. S1 in the Supplement at www.int-res.com/articles/suppl/ d145p001_supp.pdf).

Paramoeba pemaquidensis were isolated from 3 different fish species (salmon, saithe and ballan wrasse). The 2 non-salmonid species were collected from net-pens containing farmed salmon. The sal- 

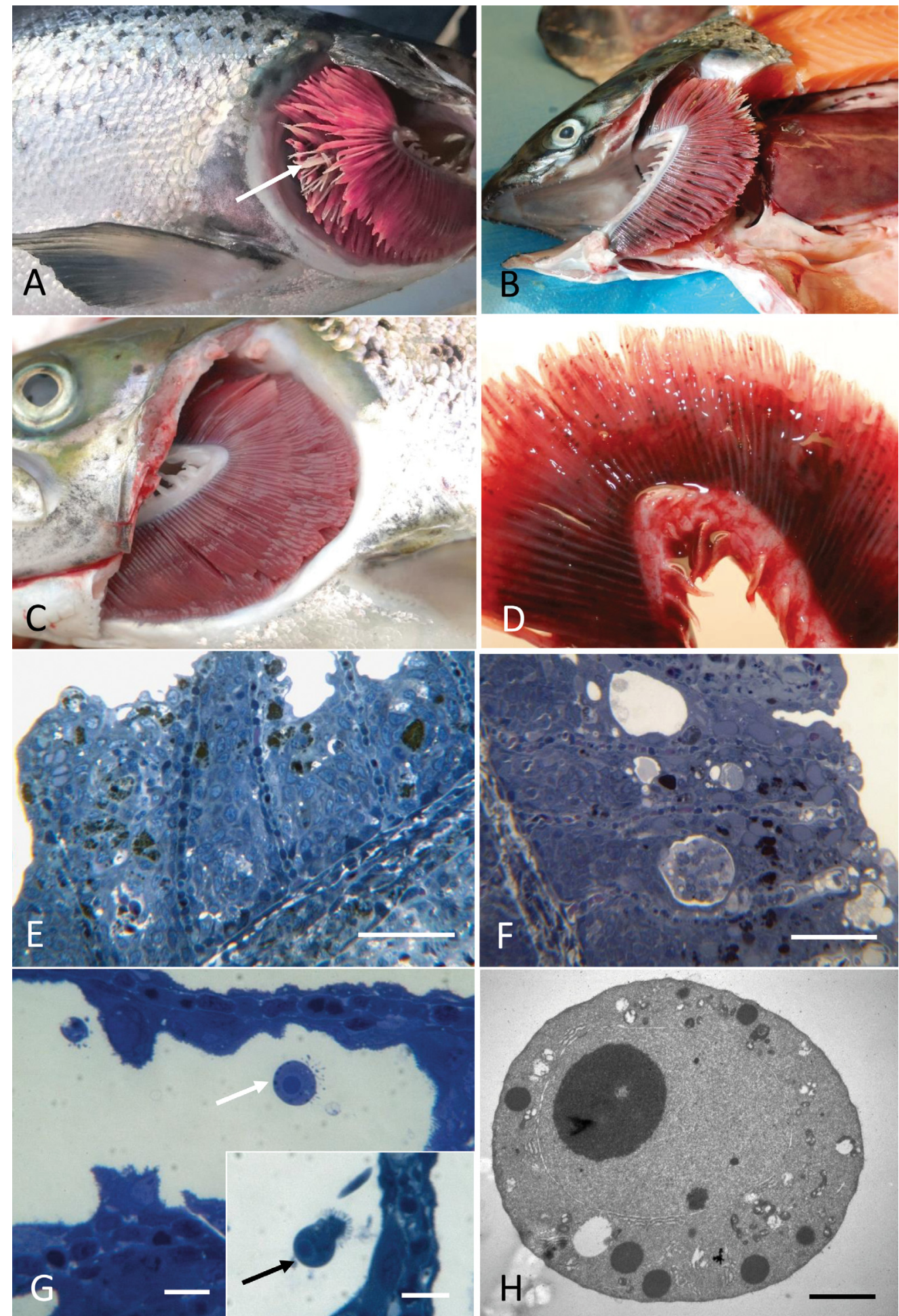

Fig. 2. Gill pathology of salmon positive for Tetramitus sp. (A,B) Gill pathology observed in the salmon from Hordaland county. In panel $A$, note the necrotic area with loss of tissue (arrow). (C,D) Gill pathology observed in the salmon from Sogn og Fjordane where some had pale gills with increased mucus production (C) while others had distinct gill bleeding (aneurisms, D). $(\mathrm{E}, \mathrm{F})$ Histopathological changes in the gills believed to be associated with Paranucleospora theridion (E) and Candidatus Branchiomonas cysticola $(\mathrm{F})(\mathrm{bars}=50 \mu \mathrm{m})$. $(\mathrm{G}, \mathrm{H})$ Amoeba-like cells (arrows) associated with the gills of salmon suffering from gill disease (bars $=10 \mu \mathrm{m}$ ). Panel $\mathrm{H}$ shows a transmission electron microscopic image of these cells (note the large nucleus and the distinct nucleolus) (bar $=2.0 \mu \mathrm{m})$ 

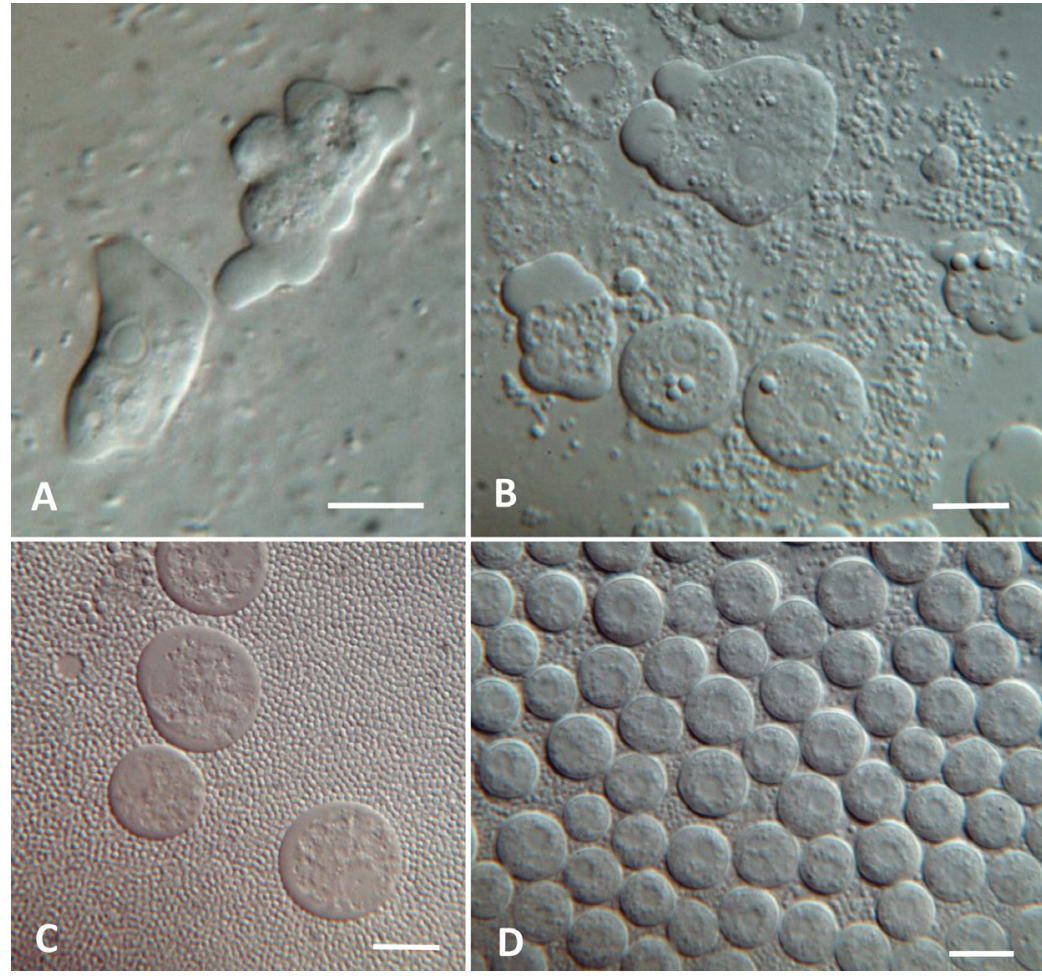

Fig. 3. Clonal culture of Tetramitus sp. (SF05/13T) showing (A) trophozoites, $(B, C)$ early stages of spore formation and $(D)$ spores (bars $=10 \mu \mathrm{m})$

gene from clone H13/13V (Fig. 5) of Vannella sp. showed a close relationship to $V$. contorta (accession no: DQ229953) isolated from seawater from the north edge of the Ross Sea pack ice (Moran et al. 2007) (Fig. S3). This clone was not used in the challenge experiments.

\subsection{Challenge experiment}

None of the salmon (shedders or cohabitants) died during the experimental period after challenge. However, both the shedders and co-habitants challenged with the 3 clones of $P$. perurans (H04/14Pp, MR06/14Pp, SF11/ 15Pp) developed AGD. The percentages of maximum gill score for the shedders and co-habitants sampled during the experimental period differed among the 3 clones of $P$. perurans (Fig. 6). The gill score increased from the first to the last sampling, both among the shedders and the co-habitants. In the last sampling of the shed-

mon in these 3 farms were suffering from GD, and $P$. perurans were present on some of the salmon in the cages. The $P$. pemaquidensis clone $\mathrm{H} 17 / 15 \mathrm{Pq}$ was isolated from salmon whose gills had patches of mucus, hyperplasia and aneurisms, and were positive for a range of pathogens, including ISAV (HPR0), IPNV, SGPV, Cand. Branchiomonas cysticola, Paranucleospora theridion, Ichthyobodo salmonis, $P$. perurans and $P$. pemaquidensis. The gills from saithe and ballan wrasse, from which H09/ $14 \mathrm{Pq}$ and $\mathrm{H} 10 / 14 \mathrm{Pq}$ were isolated, showed no sign of GD. The morphology of the clonal isolate of $P$. pemaquidensis obtained from ballan wrasse (H09/ 14Pq), saithe $(\mathrm{H} 10 / 14 \mathrm{Pq})$ and salmon $(\mathrm{H} 17 / 15 \mathrm{Pq})$ is shown in Fig. 4. Phylogenetic analyses of the $3 P$. pemaquidensis clones (H09/14Pq [MT665807], H10/ 14Pq [MT665808], H17/15Pq [MT665809]) show that they group close to each other within a clade containing isolates from Australia and the USA (Fig. S2).

Vannella sp. was isolated from salmon lice Lepeophtheirus salmonis that were present on salmon suffering from AGD. Using the real-time RT-PCR assay targeting Vannella sp. (Table 2) showed that this species was not present on the salmon gills that were heavily infected with $P$. perurans. The SSU rRNA ders challenged with H04/14Pp, MR06/14Pp and SF11/15Pp, 14, 63 and 2 gill sides, respectively, reached a gill score $\geq 3$ (out of a total of 160 sides, i.e. 16 sides in 10 individuals). Of these 3 clones, collected in 3 different counties in Norway, MR06/14Pp showed the highest virulence (gill scores) at $12^{\circ} \mathrm{C}$ (Fig. 6). The experiment was terminated before the gill score reached a level associated with mortality. In the 2 control groups, only 2 (Con-I) and 3 (Con-II) individuals ( $\mathrm{N}=60$ for each control group) had a gill score $=1$ on one side of a gill arch, respectively. The controls were negative for the presence of $P$. perurans.

Gill tissues from 10 salmon were sampled at 6, 13 and $20 \mathrm{dpc}$ from the shedder groups, while the same number of salmon were sampled at 11, 18 and $25 \mathrm{dpc}$ from the co-habitant groups. The results of the realtime RT-PCR screening for P. perurans present on the salmon gills are given in Table 3. Based on the MNE of $P$. perurans (SSU rRNA) on the gills of the salmon, in the successive samplings of the shedders, there was an increase in the number of amoebae with increasing number of dpc (Fig. 7). The MNE of $P$. perurans RNA levels in the co-habitants increased from 11 to $18 \mathrm{dpc}$, followed by a drop in the period from 18 to 25 dpc. Histopathological changes in the gills of salmon challenged with $P$. perurans included 

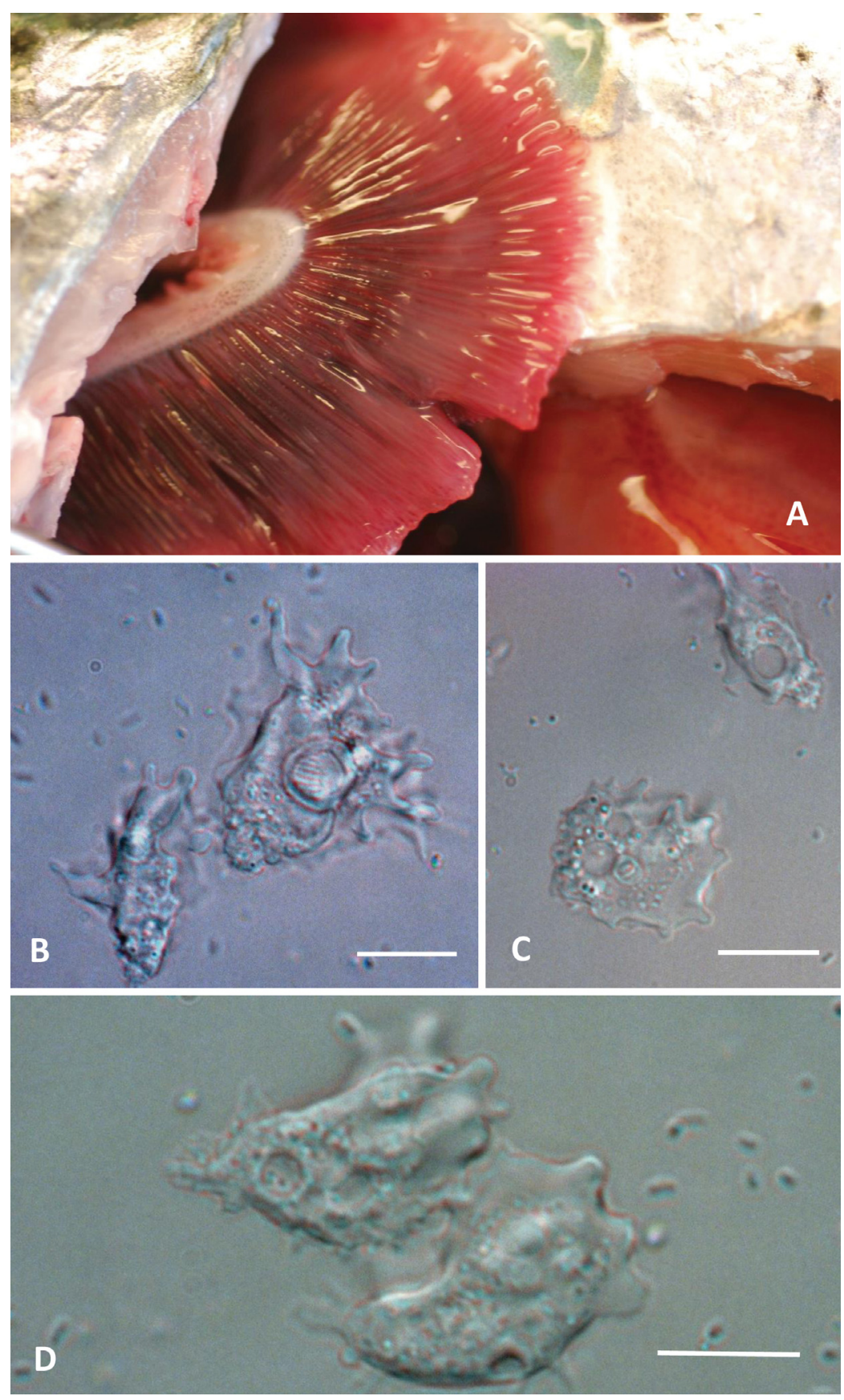

Fig. 4. (A) Gill arch from salmon diagnosed with amoebic gill disease (AGD) and positive for Paramoeba pemaquidensis and $P$. perurans. The gills are slightly pale and show areas with high mucus production. Also shown are trophozoites of $P$. pemaquidensis from clonal cultures obtained from (B) ballan wrasse (H09/14Pq), (C) saithe (H10/14Pq) and (D) salmon (H17/15Pq), respectively (bars $=10 \mu \mathrm{m})$

increased numbers of mucus cells and hyperplasia. $P$. perurans was isolated from the salmon in all tanks challenged with clones MR06/1Pp, SF11/15Pp and H04/14Pp.
None of the groups challenged with P. pemaquidensis (H17/15Pq and H09/ 14Pq) and Tetramitus sp. (H16/15T) reached a total gill score above $2.0 \%$ of the maximum gill score. The highest gill score (=2) was seen on 3 gill sides of 1 salmon in the shedder group, challenged with H16/15T and collected 20 dpc. The percentage of fish with gill scores was only slightly higher in the groups challenged with $P$. pemaquidensis and Tetramitus sp. compared to that observed in the control groups (Fig. 8).

The result of the real-time RT-PCR testing of gills for presence of $P$. pemaquidensis, from shedders and cohabitants, using the NeoUni assay is presented in Table 3. The prevalence of $P$. pemaquidensis on the gills of shedders and co-habitants challenged with H09/14Pq was higher compared to that of the salmon challenged with H17/15Pq. The highest prevalence for both groups was observed among the co-habitants at $18 \mathrm{dpc}$, but cycle threshold $\left(C^{\mathrm{T}}\right)$ values $(>19.0)$ indicate a relatively low amount of amoebae on the gills of salmon in both groups at all sampling points. Real-time RT-PCR testing of the salmon challenged with H16/15T (Tssu assay) resulted in 1 positive shedder (out of 30 total) and 1 positive co-habitant (out of 30). None of the controls were positive for any of the amoebae. Histological examination of the salmon challenged with $P$. pemaquidensis and Tetramitus sp. showed no changes in the gill tissues. It was not possible to isolate $P$. pemaquidensis and Tetramitus sp. from the challenged groups at the end of the experimental period.

\section{DISCUSSION}

Paramoeba perurans has caused AGD among farmed salmon in western Norway since 2012, with up to $90 \%$ mortality in some farms (A. Nylund pers. obs.). However, other gill pathogens and other pathogens are also always present in the salmon at the sites where AGD occurs. 

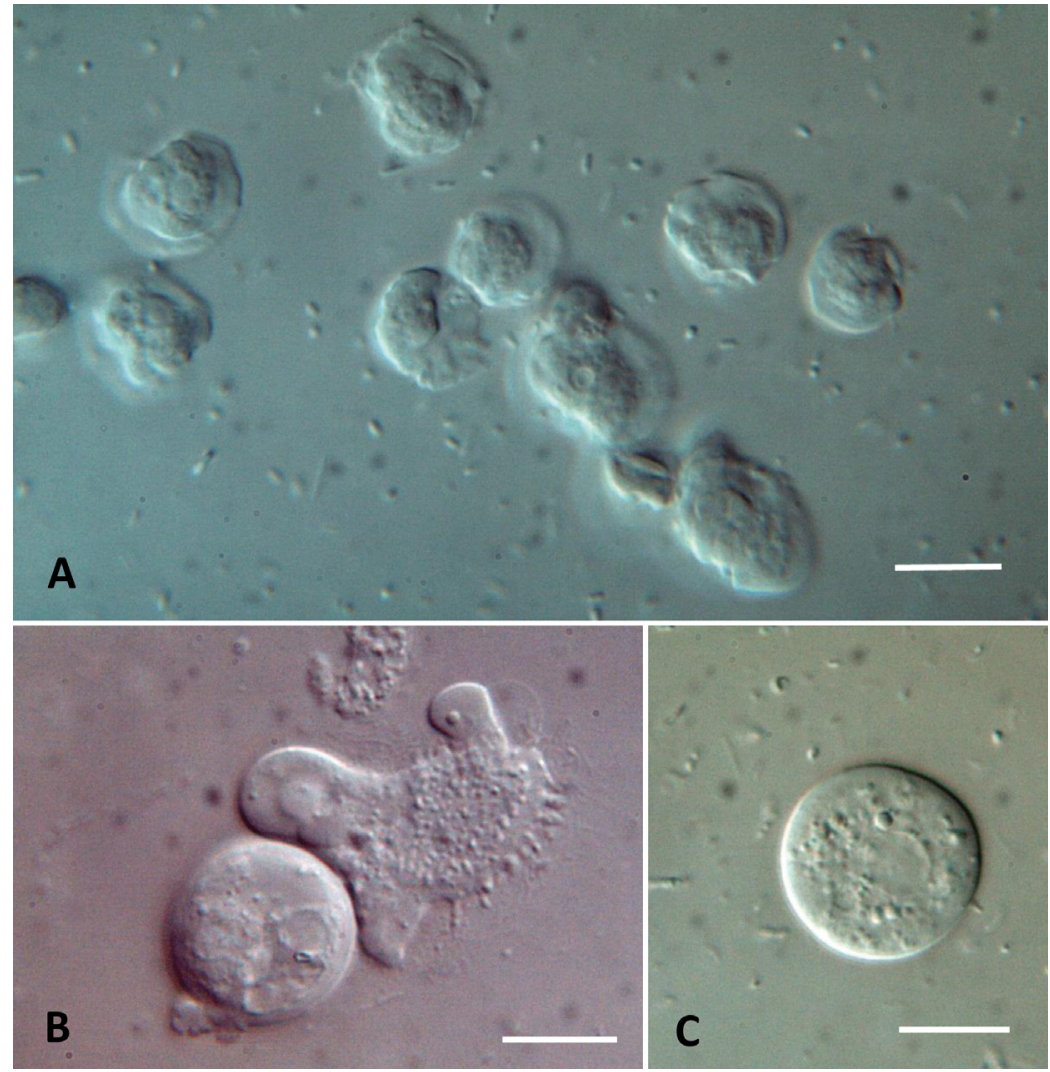

Fig. 5. (A,B) Clonal cultures (clone H13/13V) of Vannella sp. isolated from Lepeophtheirus salmonis, present on salmon with gill disease, showing motile trophonts. (C) Cyst of Vannella sp. (bars $=10 \mu \mathrm{m}$ )

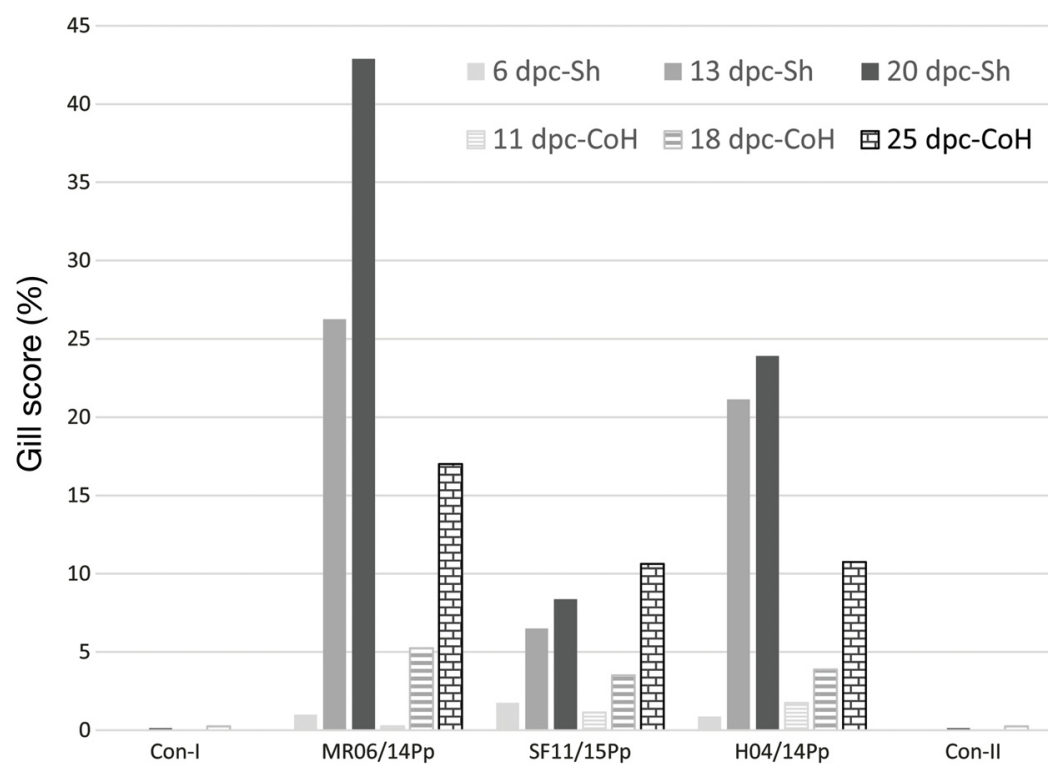

Fig. 6. Percentage gill score (y-axis) for 3 clones of Paramoeba perurans compared to the 2 control groups (Con). Sh: shedders; $\mathrm{CoH}$ : co-habitants; dpc: days post challenge. The gill score is presented as a percentage of the maximum gill score. $\mathrm{N}=10$ for each sampling
The dominating gill pathogens in western Norway are SGPV, low virulent ISAV (HPR0), Paranucleospora theridion (syn. Desmozoon lepeophtheirii), Paramoeba perurans (syn. Neoparamoeba perurans), Ichthyobodo salmonis and Candidatus Branchiomonas cysticola. These are common pathogens associated with GD in salmon aquaculture (Nylund et al. 2008, 2011, Downes et al. 2018, Herrero et al. 2018). In the present study, we also isolated other amoebae from farmed salmon with GD in western Norway: Paramoeba pemaquidensis, Tetramitus sp. and Vannella sp. $P$. pemaquidensis was isolated from ballan wrasse (isolate H09/14Pq), saithe (isolate H10/ 14Pq) and salmon (isolate H17/ 15Pq), while Tetramitus sp. was isolated from salmon only (isolates SF05/13T and H16/15T).

Vannella sp. was isolated from salmon lice, and it has been suggested that this parasite could be a vector for spreading of $P$. perurans (Nowak et al. 2010). A high diversity of Vannella spp. has previously been found on the gills of salmon and, even though the role that these amoebae may play in disease development is unknown, they are considered to be non-pathogenic (English et al. 2019). In our study, Vannella sp. was not found on any of the farmed salmon gills tested, so it was decided not to include this species in the challenge experiment.

A high diversity of amoebae associated with gills of farmed salmon have previously been observed in both Ireland and Australia (Bermingham \& Mulcahy 2007, English et al. 2019), and challenge experiments using isolates of $P$. pemaquidensis have been performed (Kent et al. 1988, Morrison et al. 2005). However, our study is the first challenge experiment using clonal cultures of $P$. pemaquidensis and Tetramitus sp. isolated from salmon in Norway. Both P. pemaquidensis and Tetrami- 
Table 3. Real-time RT-PCR detection of Paramoeba perurans (Pp), P. pemaquidensis (Pq) and Tetramitus sp. (T) on salmon shedders and co-habitants in the challenge experiment. The co-habitants were challenged $7 \mathrm{~d}$ after the shedders. Pos $\mathrm{N}=$ number of positive salmon/number of tested salmon; dpc: days post challenge

\begin{tabular}{|c|c|c|c|c|c|c|c|c|c|}
\hline \multirow[t]{2}{*}{ Shedders } & \multirow[t]{2}{*}{ Pos N } & \multicolumn{2}{|c|}{$6 \mathrm{dpc}-$} & \multirow[t]{2}{*}{ Pos N } & \multicolumn{2}{|c|}{$-13 \mathrm{dpc}-$} & \multirow[t]{2}{*}{ Pos N } & \multicolumn{2}{|c|}{$-20 \mathrm{dpc}-$} \\
\hline & & Mean Ct & Range of $\mathrm{Ct}$ & & Mean Ct & Range of $\mathrm{Ct}$ & & Mean Ct & Range of $\mathrm{Ct}$ \\
\hline MR06/14Pp & $10 / 10$ & 21.8 & $17.5-27.1$ & $10 / 10$ & 18.4 & $14.4-24.5$ & $10 / 10$ & 16.6 & $12.2-19.7$ \\
\hline SF11/15Pp & $10 / 10$ & 27.8 & $24.1-33.2$ & $10 / 10$ & 21.2 & $13.9-25.4$ & $10 / 10$ & 18.2 & $11.2-23.1$ \\
\hline $\mathrm{H} 04 / 14 \mathrm{Pp}$ & $10 / 10$ & 22.1 & $19.2-26.1$ & $10 / 10$ & 16.5 & $12.9-20.1$ & $10 / 10$ & 15.2 & $10.2-19.8$ \\
\hline $\mathrm{H} 16 / 15 \mathrm{~T}$ & $1 / 10$ & 36.7 & - & $0 / 10$ & - & - & $0 / 10$ & - & - \\
\hline $\mathrm{H} 17 / 15 \mathrm{Pq}$ & $4 / 10$ & 28.25 & $27.8-28.9$ & $4 / 10$ & 29.7 & $28.5-31.2$ & $1 / 10$ & 29.0 & - \\
\hline $\mathrm{H} 09 / 14 \mathrm{Pq}$ & $1 / 10$ & 24.1 & - & $8 / 10$ & 27.2 & $23.7-28.9$ & $5 / 9$ & 27.1 & $21.6-29.5$ \\
\hline \multirow[t]{2}{*}{ Co-habitants } & \multirow[t]{2}{*}{ Pos N } & \multicolumn{2}{|c|}{$-11 \mathrm{dpc}-$} & \multirow[t]{2}{*}{ Pos $\mathrm{N}$} & \multicolumn{2}{|c|}{$-18 \mathrm{dpc}-$} & \multirow[t]{2}{*}{ Pos N } & \multicolumn{2}{|c|}{$-25 \mathrm{dpc}-$} \\
\hline & & Mean Ct & Range of $\mathrm{Ct}$ & & Mean Ct & Range of $\mathrm{Ct}$ & & Mean Ct & Range of $\mathrm{Ct}$ \\
\hline MR06/14Pp & $10 / 10$ & 22.0 & $19.0-27.6$ & $10 / 10$ & 20.7 & $15.0-26.3$ & $10 / 10$ & 18.9 & $14.8-22.2$ \\
\hline SF11/15Pp & $10 / 10$ & 29.3 & $25.0-35.2$ & $10 / 10$ & 22.2 & $14.8-30.9$ & $10 / 10$ & 19.7 & $13.3-26.1$ \\
\hline $\mathrm{H} 04 / 14 \mathrm{Pp}$ & $9 / 10$ & 28.3 & $19.2-32.6$ & $10 / 10$ & 20.3 & $13.0-23.6$ & $10 / 10$ & 20.7 & $15.0-28.1$ \\
\hline $\mathrm{H} 16 / 15 \mathrm{~T}$ & $1 / 10$ & $25-5$ & - & $0 / 10$ & - & - & $0 / 10$ & - & - \\
\hline $\mathrm{H} 17 / 15 \mathrm{Pq}$ & $2 / 10$ & 27.6 & $25.2-29.9$ & $8 / 10$ & 25.8 & $19.1-29.9$ & $3 / 10$ & 27.1 & $24.8-28.7$ \\
\hline $\mathrm{H} 09 / 14 \mathrm{Pq}$ & $2 / 10$ & 27.5 & $25.3-29.7$ & $10 / 10$ & 26.6 & $22.1-29.4$ & $9 / 10$ & 26.8 & $23.3-28.5$ \\
\hline
\end{tabular}

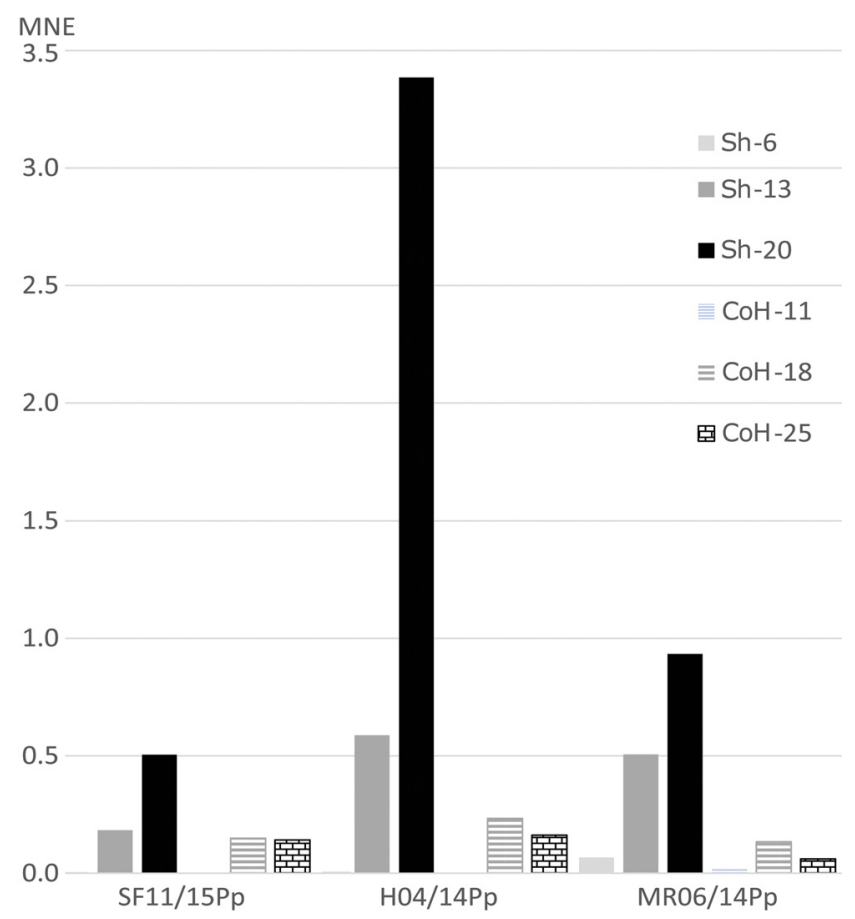

Fig. 7. Mean normalized expression (MNE) of Paramoeba perurans rRNA on the gills of 10 salmon collected at each time point. Sh: shedders (collected 6, 13 and $20 \mathrm{dpc}$ ); $\mathrm{CoH}$ : cohabitants (collected 11, 18 and $25 \mathrm{dpc}$ )

tus sp. used in the challenge were isolated from salmon with severe GD. However, they were not able to cause any GD in this experiment carried out at $12^{\circ} \mathrm{C}$ using pathogen-free salmon. The gill score of

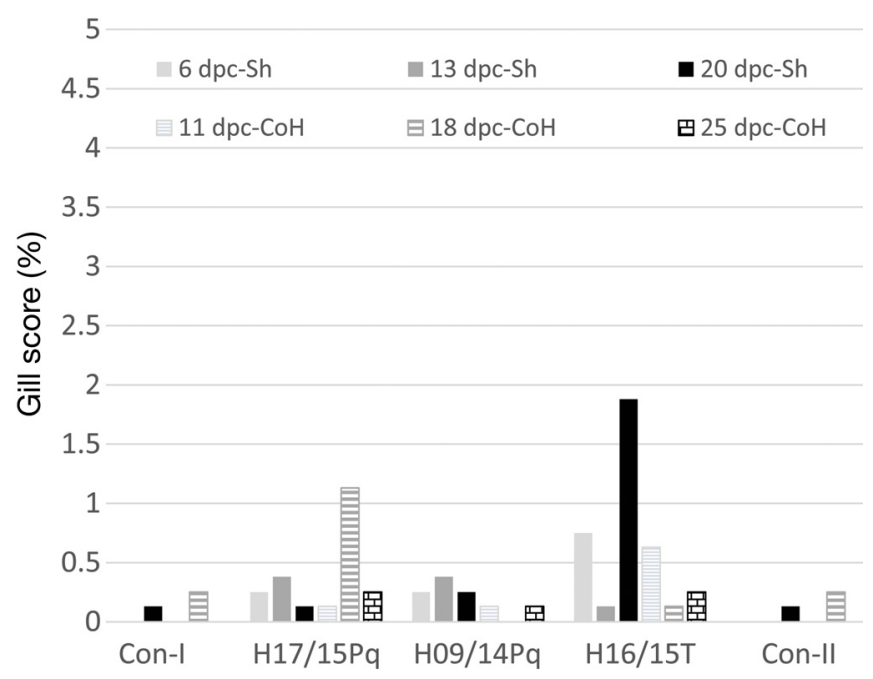

Fig. 8. Percentage gill score ( $y$-axis) for 2 clones of Paramoeba pemaquidensis (H09/14Pq, H17/15Pq) and 1 clone of Tetramitus sp. (H16/15T) compared to the 2 control groups (Con). Sh: shedders; $\mathrm{CoH}$ : co-habitants; dpc: days post challenge. The gill score is presented as a percentage of the maximum gill score. Note that the $y$-axis only covers the range $0-5 \%$

the salmon in the tanks during the experimental period was only slightly different from that found in the control groups, and only low amounts of $P$. pemaquidensis could be detected on the gills of challenged salmon. This finding supports previous studies suggesting that $P$. pemaquidensis in not the causative agent of AGD (Morrison et al. 2005, Young et al. 2007, 2008). To our knowledge, Tetramitus sp. has only been isolated from the gills of salmon in 
Norway, and according to the challenge experiment, this amoeba is not able to cause AGD in a pathogenfree environment. Tetramitus sp. is probably a freeliving non-pathogenic amoeba that can be accidently found on salmon in farms.

In the challenge experiment, clonal cultures of 3 different strains of $P$. perurans gave a distinct increase in gill score in both the shedders and the cohabitants during the experimental period. The experiment was terminated before any mortality occurred, but based on the increasing gill score during the experimental period, it is safe to conclude that $P$. perurans may cause severe AGD and mortality at $12^{\circ} \mathrm{C}$ even in the absence of other pathogens. It has been suggested that temperatures above $12^{\circ} \mathrm{C}$ represent an important risk factor for AGD outbreaks (Benedicenti et al. 2019), and in Norway, the majority of AGD outbreaks occur in the autumn at temperatures between 15 and $18^{\circ} \mathrm{C}$. However, the present study shows that $P$. perurans may also cause AGD at $12^{\circ} \mathrm{C}$ with a gill score as high as 4 on individual gill arches $20 \mathrm{dpc}$. The increase in gill score coincided with an increase in the amount of $P$. perurans rRNA detected by real-time RT-PCR at the same sampling points. The $P$. perurans clone causing the highest gill score (MR06/14Pp) was isolated from salmon in the northern part of western Norway. These results suggest that $P$. perurans has the potential to spread north of western Norway and may even cause AGD in the southern parts of northern Norway, where temperatures are higher than $12^{\circ} \mathrm{C}$ during summer and autumn. AGD caused by $P$. perurans has been observed in February at $9^{\circ} \mathrm{C}$ in a semi-closed containment system in western Norway (A. Nylund pers. obs.).

\section{CONCLUSIONS}

The present study gives no support to the hypothesis that Paramoeba pemaquidensis and Tetramitus sp. are important factors for the development of GD among Norwegian farmed salmon. P. perurans seems to be the only amoeba isolated from gills of farmed salmon and marine fish in Norway that is able to cause AGD, confirming several other studies performed during the last decade (Crosbie et al. 2012, Bridle et al. 2015, Røed 2016, Chalmers et al. 2017, Kindt 2017, Dahle et al. 2020).

Acknowledgements. This study was funded by The Norwegian Seafood Research Fund (Project: 901053).

\section{LITERATURE CITED}

Adams MB, Nowak BF (2004) Experimental amoebic gill disease of Atlantic salmon, Salmo salar L.: further evidence for the primary pathogenic role of Neoparamoeba sp. (Page, 1987). J Fish Dis 27:105-113

*Benedicenti O, Secombes CJ, Collins C (2019) Effects of temperature on Paramoeba perurans growth in culture and the associated microbial community. Parasitology 146:533-542

* Bermingham ML, Mulcahy MF (2007) Neoparamoeba sp. and other protozoans on the gills of Atlantic salmon Salmo salar smolts in seawater. Dis Aquat Org 76: 231-240

* Bridle AR, Davenport D, Crosbie PBB, Polinski M, Nowak BF (2015) Neoparamoeba perurans loses virulence during clonal culture. Int J Parasitol 45:575-578

* Bustos PA, Young ND, Rozas MA, Bohle HM, Ildefonso RS, Morrison RN, Nowak BF (2011) Amoebic gill disease (AGD) in Atlantic salmon (Salmo salar) farmed in Chile. Aquaculture 310:281-288

* Chalmers L, Taylor JF, Roy W, Preston AC, Migaud H, Adams A (2017) A comparison of disease susceptibility and innate immune response between diploid and triploid Atlantic salmon (Salmo salar) siblings following experimental infection with Neoparamoeba perurans, causative agent of amoebic gill disease. Parasitology 144: 1229-1242

Crosbie PBB, Bridle AR, Cadoret K, Nowak BF (2012) In vitro cultured Neoparamoeba perurans causes amoebic gill disease in Atlantic salmon and fulfils Koch's postulates. Int J Parasitol 42:511-515

*Dahle OMV, Blindheim SH, Nylund A, Karlsbakk E, Breck O, Glosvik H, Andersen L (2020) Atlantic salmon Salmo salar and ballan wrasse Labrus bergylta display different susceptibility to clonal strains of Paramoeba perurans. Dis Aquat Org 140:55-72

Douglas-Helders M, Nowak B, Zilberg D, Carson J (2000) Survival of Paramoeba pemaquidensis on dead salmon: implications for management of cage hygiene. Bull Eur Assoc Fish Pathol 20:167-169

* Downes JK, Yatabe T, Marcos-Lopez M, Rodger HD and others (2018) Investigation of co-infections with pathogens associated with gill disease in Atlantic salmon during amoebic gill disease outbreak. J Fish Dis 41: 1217-1227

* Duesund H, Nylund S, Watanabe K, Ottem KF, Nylund A (2010) Characterization of a VHS virus genotype III isolated from rainbow trout (Oncorhynchus mykiss) at a marine site on the west coast of Norway. Virol J 7:19

English CJ, Tyml T, Botwright NA, Barnes AC, Wynne JW, Lima PC, Cook MT (2019) A diversity of amoebae colonise the gills of farmed Atlantic salmon (Salmo salar) with amoebic gill disease (AGD). Eur J Protistol $67: 27-45$

Gunnarsson GS, Blindheim S, Karlsbakk E, Plarre H and others (2017a) Desmozoon lepeophtherii (microsporidian) infections and pancreas disease (PD) outbreaks in farmed Atlantic salmon (Salmo salar L.). Aquaculture 468:141-148

*Haugland GT, Olsen AB, Rønneseth A, Andersen L (2017) Lumpfish (Cyclopterus lumpus, L.) develop amoebic gill disease (AGD) after experimental challenge with Paramoeba perurans and can transfer amoebae to Atlantic salmon (Salmo salar L.). Aquaculture 478:48-55 
Herrero A, Thompson KD, Ashby A, Rodger HD, Dagleish MP (2018) Complex gill disease: an emerging syndrome in farmed Atlantic salmon (Salmo salar L.). J Comp Pathol 163:23-28

Hodneland K, Endresen C (2006) Sensitive and specific detection of Salmonid alphavirus using real-time PCR (TaqMan ${ }^{\circledR}$ ). J Virol Methods 131:184-192

Isaksen TE, Karlsbakk E, Watanabe K, Nylund A (2011) Ichthyobodo salmonis sp. n. (Ichthyobodonidae, Kinetoplastida) an euryhaline ectoparasite infecting Atlantic salmon, (Salmo salar L). Parasitology 138:1164-1175

* Isaksen TE, Karlsbakk E, Repstad O, Nylund A (2012) Molecular tools for the detection and identification of Ichthyobodo spp. (Kinetoplastida), important fish parasites. Parasitol Int 61:675-683

Karlsbakk E, Sæther P, Høstlund C, Fjellsøy K, Nylund A (2002) Parvicapsula pseudobranchicola n. sp. (Myxozoa), a myxosporidian infecting the pseudobranch of cultured Atlantic salmon (Salmo salar) in Norway. Bull Eur Assoc Fish Pathol 22:381-387

Karlsbakk E, Olsen AB, Einen AC, Mo TA and others (2013) Amoebic gill disease due to Paramoeba perurans in ballan wrasse (Labrus bergylta). Aquaculture 412-413: 41-44

Karlsen M, Nylund A, Watanabe K, Helvik J, Nylund S, Plarre H (2008) Characterization of 'Candidatus Clavochlamydia salmonicola': an intracellular bacterium infecting salmonid fish. Environ Microbiol 10:208-218

Kent ML, Sawyer TK, Hedrick RP (1988) Paramoeba pemaquidensis (Sarcomastigophora: Paramoebidae) infestation of the gills of coho salmon (Oncorhynchus kisutch) reared in sea water. Dis Aquat Org 5:163-169

Kim WS, Kong KH, Kim JO, Jung AJ, Kim JH, Oh MJ (2017) Amoebic gill disease outbreak in marine fish cultured in Korea. J Vet Diagn Invest 29:357-361

Kindt M (2017) Eksperimentell smitte med Paramoeba perurans og utvikling av amøbisk gjellesykdom hos Atlantisk laks (Salmo salar, L). Påvirker vanntemperaturen virulensen hos klonale isolater av amøben? MSc thesis, University of Bergen

Mitchell SO, Steinum TM, Toenshoff ER, Kvellestad A, Falk K, Horn M, Colquhoun DJ (2013) Candidatus Branchiomonas cysticola is a common agent of epitheliocysts in seawater-farmed Atlantic salmon in Norway and Ireland. Dis Aquat Org 103:35-43

Moran DM, Anderson OR, Dennett MR, Caron DA, Gast RJ (2007) A description of seven Antarctic marine Gymnamoebae including a new subspecies, two new species and a new genus: Neoparamoeba aestuarina antarctica n. subsp., Platyamoeba oblongata n. sp., Platyamoeba contorta n. sp. and Vermistella antarctica n. gen. n. sp. J Eukaryot Microbiol 54:169-183

* Morrison RN, Crosbie PBB, Nowak BF (2004) The induction of laboratory based amoebic gill disease revisited. J Fish Dis 27:445-449

Morrison RN, Crosbie PBB, Cook MT, Adams MB, Nowak BF (2005) Cultured gill-derived Neoparamoeba pemaquidensis fails to elicit amoebic gill disease (AGD) in Atlantic salmon Salmo salar. Dis Aquat Org 66:135-144

* Mouton A, Crosbie P, Cadoret K, Nowak B (2014) First record of amoebic gill disease caused by Neoparamoeba perurans in South Africa. J Fish Dis 37:407-409

Munday BL, Zilberg D, Findlay V (2001) Gill disease of marine fish caused by infection with Neoparamoeba pemaquidensis. J Fish Dis 24:497-507
Murtagh GJ, Dyer PS, Rogerson A, Nash GV, Lybourn-Parry $\mathrm{J}$ (2002) A new species of Tetramitus in the benthos of a saline Antarctic lake. Eur J Protistol 37:437-443

Nowak BF, Bryan J, Jones SRM (2010) Do salmon lice, Lepeophtheirus salmonis, have a role in the epidemiology of amoebic gill disease caused by Neoparamoeba perurans? J Fish Dis 33:683-687

Nylund A, Kvenseth AM, Isdal E (1998) A morphological study of the epitheliocystis agent in farmed Atlantic salmon. J Aquat Anim Health 10:43-55

Nylund A, Watanabe K, Karlsen M, Nylund S, Karlsbakk E, Sæther P (2006) Ny gjellesykdom hos laks - Poxvirus. Norsk Fiskeoppdrett 31:54-56

Nylund A, Karlsen M, Watanabe K, Karlsbakk E, Nylund S, Isaksen T, Arnesen C (2007) Gjennombrudd i kampen mot PGI (proliferative gjellebetennelse). Norsk Fiskeoppdrett 32:50-53

Nylund A, Hansen H, Brevik ØJ, Hustoft H, Markussen T, Plarre H, Karlsbakk E (2018a) Infection dynamics and tissue tropism of Parvicapsula pseudobranchicola (Myxozoa: Myxosporea) in farmed Atlantic salmon (Salmo salar). Parasit Vectors 11:17

Nylund A, Pistone D, Trösse C, Blindheim S, Andersen L, Plarre H (2018b) Genotyping of Candidatus Syngnamydia salmonis (Chlamydiales; Simkaniaceae) co-cultured in Paramoeba perurans (Amoebozoa; Paramoebidae). Arch Microbiol 200:859-867

* Nylund S, Nylund A, Watanabe K, Arnesen C, Karlsbakk E (2010) Paranucleospora theridion n. gen, n. sp. (Microsporidia, Enterocytozoonidae) with a life cycle in the salmon louse (Lepeophtheirus salmonis, Copepoda) and Atlantic salmon (Salmo salar). J Eukaryot Microbiol 57: 95-114

* Nylund S, Andersen L, Sævareid I, Plarre H and others (2011) Diseases of farmed Atlantic salmon Salmo salar associated with infections by the microsporidian Paranucleospora theridion. Dis Aquat Org 94:41-57

*Nylund S, Steigen A, Karlsbakk E, Plarre H, Andersen L, Karlsen M, Nylund A (2015) Characterization of 'Candidatus Syngnamydia salmonis' (Chlamydiales, Simkaniaceae), a bacterium associated with epitheliocystis in Atlantic salmon (Salmo salar L.). Arch Microbiol 197: $17-25$

Oldham T, Rodger H, Nowak BF (2016) Incidence and distribution of amoebic gill disease (AGD) - an epidemiological review. Aquaculture 457:35-42

\% Olsvik PA, Lie KK, Jordal AEO, Nilsen TO, Hordvik I (2005) Evaluation of potential reference genes in real-time RTPCR studies of Atlantic salmon. BMC Mol Biol 6:21

* Overton K, Dempster T, Oppedal F, Kristiansen TS, Gismervik K, Stien LH (2019) Salmon lice treatments and salmon mortality in Norwegian aquaculture: a review. Rev Aquacult 11:1398-1417

* Plarre H, Devold M, Snow M, Nylund A (2005) Prevalence of infectious salmon anaemia virus (ISAV) in wild salmonids in western Norway. Dis Aquat Org 66: 71-79

Powell MD, Fisk D, Nowak BF (2000) Effects of graded hypoxia on Atlantic salmon infected with amoebic gill disease. J Fish Biol 57:1047-1057

* Powell MD, Reynolds P, Kristensen T (2015) Freshwater treatment of amoebic gill disease and sea-lice in seawater salmon production: considerations of water chemistry and fish welfare in Norway. Aquaculture 448: $18-28$ 
Røed M (2016) Eksperimentell smitte med Paramoeba perurans og AGD utvikling hos Atlantisk laks (Salmo salar, L.). En komparativ studie av virulens hos klonede isolater av $P$. perurans. MSc thesis, University of Bergen

Småge SB, Frisch K, Brevik ØJ, Watanabe K, Nylund A (2016) First isolation, identification, and characterization of Tenacibaculum maritimum in Norway, isolated from diseased farmed sea lice cleaner fish Cyclopterus lumpus L. Aquaculture 464:178-184

Steigen A, Nylund A, Karlsbakk E, Akoll P and others (2013) 'Cand. Actinochlamydia clariae' gen. nov., sp. nov., a unique intracellular bacterium causing epitheliocystis in catfish (Clarias gariepinus) in Uganda. PLOS ONE 8: e66840

Steinum T, Kvellestad A, Rønneberg LB, Nilsen H and others (2008) First cases of amoebic gill disease (AGD) in Norwegian seawater farmed Atlantic salmon, Salmo salar L., and phylogeny of the causative amoeba using 18S cDNA sequences. J Fish Dis 31:205-214

Editorial responsibility: Michael L. Kent,

Corvallis, Oregon, USA

Reviewed by: 2 anonymous referees
Taylor RS, Muller WJ, Cook MT, Kube PD, Elliott NG (2009) Gill observations in Atlantic salmon (Salmo salar, L.) during repeated amoebic gill disease (AGD) field exposure and survival challenge. Aquaculture 290:1-8

Walde CS, Jensen BB, Pettersen JM, Stormoen M (2021) Estimating cage-level mortality distributions following delousing treatments of Atlantic salmon (Salmo salar) in Norway. J Fish Dis, doi:10.1111/jfd.13348

* Young ND, Crosbie PBB, Adams MB, Nowak BF, Morrison RN (2007) Neoparamoeba perurans n. sp., an agent of amoebic gill disease of Atlantic salmon (Salmo salar). Int J Parasitol 37:1469-1481

* Young ND, Dyková I, Snekvik K, Nowak BF, Morrison RN (2008) Neoparamoeba perurans is a cosmopolitan aetiological agent of amoebic gill disease. Dis Aquat Org 78: 217-223

Kilberg D, Gross A, Munday BL (2001) Production of salmonid amoebic gill disease by exposure to Paramoeba sp. harvested from the gills of infected fish. J Fish Dis 24: $79-82$

Submitted: December 22, 2020

Accepted: March 15, 2021

Proofs received from author(s): May 25, 2021 